\title{
Antibody and Delayed-Type Hypersensitivity Responses to Ochrobactrum anthropi Cytosolic and Outer Membrane Antigens in Infections by Smooth and Rough Brucella spp.
}

\author{
J. VELASCO, ${ }^{1}$ R. DÍAZ, ${ }^{1}$ M. J. GRILLÓ, ${ }^{2}$ M. BARBERÁN, ${ }^{3}$ C. MARÍN, ${ }^{2}$ J. M. BLASCO,${ }^{2}$ \\ AND I. MORIYÓN ${ }^{1 *}$ \\ Departamento de Microbiología, Universidad de Navarra, Pamplona, ${ }^{1}$ and Departamento de Producción Animal, \\ Servicio de Investigación Agraria, Diputación General de Aragón, ${ }^{2}$ and Departamento de Histología y \\ Anatomía Patológica, Facultad de Veterinaria, Universidad de Zaragoza, ${ }^{3}$ Zaragoza, Spain
}

Received 4 November 1996/Returned for modification 18 December 1996/Accepted 24 January 1997

\begin{abstract}
Immunological cross-reactions between Brucella spp. and Ochrobactrum anthropi were investigated in animals and humans naturally infected by Brucella spp. and in experimentally infected rams (Brucella ovis infected), rabbits (Brucella melitensis infected), and mice (B. melitensis and Brucella abortus infected). In the animals tested, $O$. anthropi cytosolic proteins evoked a delayed-type hypersensitivity reaction of a frequency and intensity similar to that observed with $B$. melitensis brucellin. $O$. anthropi cytosolic proteins also reacted in gel precipitation tests with antibodies in sera from Brucella natural hosts with a frequency similar to that observed with $B$. melitensis proteins, and absorption experiments and immunoblotting showed antibodies to both Brucella-specific proteins and proteins common to Brucella and $O$. anthropi. No antibodies to $O$. anthropi cytosolic proteins were detected in the sera of Brucella-free hosts. Immunoblotting with sera of Brucella-infected sheep and goats showed immunoglobulin G (IgG) to Brucella group 3 outer membrane proteins and to $O$. anthropi proteins of similar molecular weight. No IgG to the $\mathrm{O}$-specific polysaccharide of $O$. anthropi lipopolysaccharide was detected in the sera of Brucella-infected hosts. The sera of sheep, goats, and rabbits infected with $B$. melitensis contained IgG to $O$. anthropi rough lipopolysaccharide and lipid A, and $B$. ovis and $O$. anthropi rough lipopolysaccharides showed equal reactivities with IgG in the sera of $B$. ovis-infected rams. The findings show that the immunoresponse of Brucella-infected hosts to protein antigens is not necessarily specific for brucellae and suggest that the presence of $O$. anthropi or some related bacteria explains the previously described reactivities to Brucella rough lipopolysaccharide and outer membrane proteins in healthy animals.
\end{abstract}

Members of the genus Brucella are gram-negative bacteria that cause brucellosis, an infectious disease affecting livestock and humans, and whose laboratory diagnosis is usually performed by bacteriological and serological tests $(4,15)$. Whereas standard tests for infections caused by smooth (S) Brucella spp. (Brucella melitensis, Brucella abortus, and Brucella suis) detect antibodies to the outer membrane (OM) S-lipopolysaccharide (S-LPS) $(4,15,50)$, tests used for infections caused by the rough (R) species Brucella ovis detect antibodies to the R-LPS and to some OM proteins (39). Brucella spp. also elicit an immune response to soluble protein antigens which can be detected in serological $(14,15,17,28,37,42,43,46,51)$ and delayed-type-hypersensitivity (DTH) tests $(7,20)$.

Serological cross-reactions between the S-LPSs of Brucella and of some gram-negative bacteria, most notably Yersinia enterocolitica O:9, have been described and characterized at the molecular level (38) and are a cause of false-positive results in standard serological tests for brucellosis (4). On the other hand, an immunological cross-reactivity between proteins of Brucella spp. and of other bacteria has never been reported with sera from naturally infected hosts or in studies with hyperimmune sera $(11,13)$. For this reason, and because protein

\footnotetext{
* Corresponding author. Mailing address: Departamento de Microbiología, Universidad de Navarra, Aptdo. 177, 31080 Pamplona, Spain. Phone: 34-48-425600. Fax: 34-48-425649. E-mail: imoriyon@mail2.cti .unav.es.
}

antigens are largely shared by all Brucella spp. (13), tests detecting antibodies or DTH reactions to Brucella proteins are considered specific for the genus $(15,18)$.

Ochrobactrum anthropi is a gram-negative bacterium which encompasses strains formerly included in the Centers for Disease Control and Prevention Vd group (27) and which is isolated with increasing frequency from immunocompromised patients as well as in other situations $(2,9,19,25,29,47)$. Analysis of the $16 \mathrm{~S}$ rRNA has placed $O$. anthropi in the alpha subdivision of Proteobacteria, with a close proximity to Brucella (34). Moreover, some $O$. anthropi strains are positive in a PCR test for the diagnosis of Brucella infections (41). Thus, the possibility that Brucella and O. anthropi show a hitherto-unnoticed antigenic cross-reactivity exists. Immunological cross-reactivities between taxonomically related bacteria have been observed by using hyperimmune sera (8), but it is possible that such cross-reactions could also be observed with sera from naturally infected hosts. In fact, we have observed that sera from brucella-free hosts show unexpectedly high reactivities with R-LPS and some OM proteins $(21,23,39)$ and that immunocompromised patients who become infected by $O$. anthropi develop antibodies to Brucella proteins (33). Since antiprotein tests are receiving increasing attention for the diagnosis of brucellosis $(5,10,24,26,43,44)$, it is appropriate to study whether such a cross-reactivity can be observed in naturally Brucella-infected hosts and whether it can affect the specificity of anti-Brucella protein tests. The results of such a study are reported here. 


\section{MATERIALS AND METHODS}

Bacterial strains and growth conditions. O. anthropi LMG 3331 and LMG 3301 were obtained from the Laboratorium voor Microbiologie Gent Culture Collection (University of Ghent, Ghent, Belgium). B. melitensis 16M (S, virulent), B. melitensis 115 (R mutant, avirulent), B. ovis PA (virulent), B. ovis Reo 198 ( $\mathrm{CO}_{2}$ independent), B. abortus 2308 (S, virulent), and B. abortus RB51 (R) are strains which have been described previously $(4,7,45)$. For antigen extraction, $O$. anthropi and B. melitensis were grown in a medium consisting of $1.7 \%$ Casitone (E. Merck, Darmstadt, Germany), 0.3\% Soytone (Difco Laboratories, Detroit, Mich.), $0.5 \%$ yeast extract (Merck), $0.25 \% \mathrm{~K}_{2} \mathrm{HPO}_{4}, 2 \%$ glucose, $0.5 \%$ $\mathrm{NaCl}$, and $0.01 \%$ antifoam A-butyl acetate (1:3) (Sigma Chemical Co., St. Louis, Mo.) in a 15-liter Biostat fermentor (B. Braun Melsungen AG, Leinfelden, Germany) for $36 \mathrm{~h}$ at $36^{\circ} \mathrm{C}$ and $35 \% \mathrm{O}_{2}$ saturation. B. ovis Reo 198 was grown in tryptic soy broth (Difco Laboratories) supplemented with $2.5 \%$ yeast extract in 2-liter flasks on an orbital shaker. Cells were harvested by tangential flow filtration (Omega 100K filter; Filtron Technology Corp., Northborough, Mass.) or by centrifugation $(7,000 \times g, 15 \mathrm{~min})$ and washed twice with $0.8 \% \mathrm{NaCl}(B$. melitensis $16 \mathrm{M}$ was inactivated with phenol $\left[0.5 \%, 36^{\circ} \mathrm{C}, 48 \mathrm{~h}\right]$ before harvesting). For animal immunization or experimental infection, the appropriate strains were grown on tryptic soy agar slopes with $(B$. ovis) or without $2.5 \%$ yeast extract.

Cytosol and cell envelope fractions. B. melitensis $115, B$. ovis Reo 198, and $O$. anthropi LMG 3301 cells were disintegrated in the presence of nucleases with a 40K French pressure cell (SLM Instruments Inc., Urbana, Ill.) operating at an internal pressure of $35,000 \mathrm{lb} / \mathrm{in}^{2}(7)$. The cell envelope fraction was sedimented $\left(80,000 \times g, 2 \mathrm{~h}, 4^{\circ} \mathrm{C}\right)$, and the supernatant was held at $4^{\circ} \mathrm{C}$ for $24 \mathrm{~h}$ before being ultracentrifuged again under the same conditions. The new supernatant (cytosol) was dialyzed against $10 \mathrm{mM}$ phosphate buffer $(\mathrm{pH}$ 7.2) (two changes of buffer in $48 \mathrm{~h}$ ) at $4^{\circ} \mathrm{C}$ and freeze-dried. Cytosols were free of cell envelope components as judged by the absence of inner membrane enzymatic markers (36), 3-deoxy-Dmanno-2-octulosonic acid (Kdo) measured colorimetrically (16), or LPS detectable by sodium dodecyl sulfate-polyacrylamide gel electrophoresis (SDS-PAGE) followed by periodate-silver staining (39). A fraction rich in OM proteins was obtained from cell envelopes by extraction with Sarkosyl (Sigma) and Zwittergent 316 (Calbiochem-Behring, San Diego, Calif.) (36). The Zwittergent 316 extract was precipitated with acetone and solubilized in $0.7 \mathrm{M} 2$-mercaptoethanol-10\% glycerol-10 mM Tris-HCl (pH 6.8) for SDS-PAGE and Western blot analyses.

LPSs and $\boldsymbol{O}$. anthropi $\boldsymbol{O}$-specific polysaccharide. B. melitensis $16 \mathrm{M}$ crude S-LPS was obtained by methanol precipitation of the phenol phase of a waterphenol extract (31), and O. anthropi S-LPS was obtained from strain LMG 3331 by the standard water-phenol method (48). The crude fractions were digested with nucleases and proteinase $\mathrm{K}$, sedimented by ultracentrifugation under the conditions described previously (16), and freeze-dried. The O-specific polysaccharide of $O$. anthropi was obtained by mild acid hydrolysis of the S-LPS (48). $O$. anthropi LMG 3301 and B. ovis Reo 198 R-LPSs were obtained by the petroleum ether-chloroform-phenol method (22). After flash evaporation of the petroleum ether and chloroform, the phenol phase was saturated with water and the precipitate was sedimented $(7,000 \times g, 20 \mathrm{~min}$, room temperature $)$ and processed as in the standard protocol to yield the R-LPS. In addition, for $O$. anthropi LMG 3301, a lipid A-rich fraction (49) was obtained by precipitating the water-saturated phenol with 10 volumes of acetone. This precipitate was sedimented $(7,000 \times g, 20 \mathrm{~min}$, room temperature), washed with acetone, dialyzed, and freeze-dried. Kdo contents for the above-described preparations were as follows: B. melitensis S-LPS, $0.9 \%$; $O$. anthropi S-LPS, $0.52 \%$; $O$. anthropi R-LPS, $1.38 \%$; and $O$. anthropi lipid A-rich fraction, $0.20 \%$. The protein content of these preparations (determined by the modified Lowry method [16]) was less than $0.2 \%$, except for the lipid A-rich fraction, which contained $4.5 \%$ protein.

Immunological tests. (i) Gel immunoprecipitations. Counterimmunoelectrophoresis (CIEP) was carried out in $1 \%$ agarose (Indubiose A37HAA; IBFBiotechnics, Villeneuve la Garenne, France) gels in $0.04 \mathrm{M}$ sodium barbital-HCl buffer ( $\mathrm{pH} 8.6)(14,17)$. Two rows of 3-mm-diameter wells were punched $1 \mathrm{~cm}$ apart, anodic wells were filled with the sera, and $20 \mu \mathrm{l}$ of cytosol $(2 \mathrm{mg}$ [dry weight] per $\mathrm{ml})$ was dispensed into the cathode wells. After electrophoresis $(1 \mathrm{~h}$ at $2 \mathrm{~V} / \mathrm{cm}$ ), the plates were incubated for $1 \mathrm{~h}$ in $5 \%$ sodium citrate and washed with distilled water for $24 \mathrm{~h}$. Immunoelectrophoresis was carried out in $1.8 \%$ agarose- $0.05 \% \mathrm{NaN}_{3}-0.04 \mathrm{M}$ sodium diethylbarbiturate- $\mathrm{HCl}(\mathrm{pH} 8.6)$ at $6 \mathrm{~V} / \mathrm{cm}$ for $2 \mathrm{~h}(12,13)$. After diffusion of the sera and immunoprecipitation $(18 \mathrm{~h}$ at $25^{\circ} \mathrm{C}$ ), the plates were soaked for $24 \mathrm{~h}$ in saline, washed with distilled water for $24 \mathrm{~h}$, air dried, and stained with $1 \%$ Coomassie R-blue in water-ethanol-acetic acid $(9: 2: 9)$. The reverse single radial diffusion test was carried out by including the proteins $(1,500$ to $200 \mu \mathrm{g}$ per $\mathrm{ml})$ in agarose-glycine buffer gels (28). Double gel immunodiffusion was carried out in the above-described agarose-barbital gels.

(ii) Western blotting. After SDS-PAGE, proteins were electroblotted onto Immobilon P membranes (Millipore Corp., Bedford, Mass.) by the semidry method by using a Trans-Blot SD apparatus (Bio-Rad Laboratories, Richmond, Calif.) according to the instructions of the manufacturers. For LPS gels, electroblotting was performed on nitrocellulose sheets (type HA, $0.45-\mu \mathrm{m}$ pore size; Millipore) in a Trans-Blot cuvette (Bio-Rad Laboratories) containing 20\% methanol, $192 \mathrm{mM}$ glycine, and $20 \mathrm{mM}$ Tris- $\mathrm{HCl}(\mathrm{pH} 8.3)$ at $200 \mathrm{~mA}$ for $5 \mathrm{~h}$. After incubation with the appropriate sera, blots were developed with peroxidase- conjugated protein G (Pierce Chemical Co., Rockford, Ill.) and 4-chloro-1naphthol- $\mathrm{H}_{2} \mathrm{O}_{2}$ (39).

(iii) Indirect ELISA. Standard 96-well polystyrene plates (Inotech-ELISA Bioreba, Basel, Switzerland) were coated with $100 \mu$ l of the appropriate antigen (S-LPS, R-LPS, or lipid A-rich fraction) per well at $2.5 \mu \mathrm{g}$ (dry weight) per ml in $10 \mathrm{mM}$ phosphate buffer ( $\mathrm{pH} \mathrm{7.2)}$. After overnight incubation at $4^{\circ} \mathrm{C}$, nonadsorbed material was removed with four washings of the same buffer solution containing $0.05 \%$ Tween 20 , and the plates were stored dry at $4^{\circ} \mathrm{C}$ until used. The remaining enzyme-linked immunosorbent assay (ELISA) steps were performed as described previously (17) with peroxidase-protein G (Pierce) as the immunoglobulin $\mathrm{G}$ ( $\mathrm{IgG}$ )-specific conjugate and $0.1 \%$ 2,2' -azinobis(3-ethylbenz-thiazoline-6-sulfonic acid) (diammonium salt; ABTS [Sigma]) in $0.05 \mathrm{M}$ citrate buffer ( $\mathrm{pH} 4$ ) with $0.004 \% \mathrm{H}_{2} \mathrm{O}_{2}$ as the developing substrate.

(iv) DTH tests. Two experiments were conducted. In the first experiment, 6-week-old BALB/c mice were used. Groups of five mice were inoculated intraperitoneally with either $5 \times 10^{4} \mathrm{CFU}$ of $B$. melitensis $16 \mathrm{M}$ or $5 \times 10^{4} \mathrm{CFU}$ of $B$. abortus 2308 or with saline $(0.1 \mathrm{ml})$ as a control. Five weeks later, all mice were injected intradermally in the rear footpads with $20 \mu \mathrm{l}$ of a $0.8-\mathrm{mg} / \mathrm{ml}$ solution of cytosols from B. melitensis 115 (right footpad) or O. anthropi (left footpad). All mice were killed $48 \mathrm{~h}$ later, and the whole footpads were fixed in Bouin's solution, embedded in paraffin, and processed for microscopic examination of lesions.

In the second experiment, a total of 14 Brucella-free rams were inoculated by the conjunctival and preputial routes with $1.2 \times 10^{9} \mathrm{CFU}$ of $B$. ovis PA. Two months later, all rams were tested by intradermal inoculation of $O$. anthrop cytosol $(150 \mu \mathrm{g}$ [dry weight] in $0.1 \mathrm{ml}$ of $0.15 \mathrm{M} \mathrm{NaCl})$ in the skin of the tail and, simultaneously, by subcutaneous inoculation of brucellin (brucellin OCB, batch $26 \mathrm{~N}$ 151; Rhone-Merieux, Lyon, France) in the right lower eyelid at the dose recommended by the manufacturer. After $72 \mathrm{~h}$, the intensity of the reactions was evaluated by microscopic examination of samples taken at necropsy from inoculation sites (7). All of the rams were found to be infected with B. ovis by bacteriological culture of necropsy specimens.

Immune and control sera. Sera were obtained as follows.

(i) Humans. Sera were obtained from 24 brucellosis patients who were blood culture positive for $B$. melitensis and who had serum agglutination titers of $\geq 320$ and from 10 healthy donors.

(ii) Cattle. Sera were drawn from 20 cattle which were positive in both the rose bengal and complement fixation tests (4) for brucellosis (titers $>256$ ) from herds in which B. abortus had been isolated and also from 66 Brucella-free cattle.

(iii) Sheep. Sera were taken from 36 ewes bacteriologically positive for $B$. melitensis and also positive in both the rose bengal and complement fixation tests (titers $\geq 32$ ) and from 66 Brucella-free sheep. In addition, sera from 14 rams which had been inoculated with $1.2 \times 10^{9} \mathrm{CFU}$ of $B$. ovis PA and which were found to be infected at necropsy and from 15 Brucella-free rams were used.

(iv) Goats. Sera were drawn from 36 goats which were milk culture positive for $B$. melitensis and positive in the rose bengal and complement fixation tests (titers $\geq 32$ ) and from 66 Brucella-free goats.

(v) Rabbits. New Zealand White female rabbits were inoculated with $10^{9} \mathrm{CFU}$ of $B$. melitensis $16 \mathrm{M}$ by the intravenous route (12) and bled 15 days and 1,3 , and 6 months after inoculation. A second group of animals was immunized by intraperitoneal injection of live cells of $O$. anthropi LMG $3301\left(10^{9} \mathrm{CFU}\right.$, nine injections at 2-day intervals). In addition, groups of rabbits were hyperimmunized with acetone-killed cells of either B. melitensis 115 or O. anthropi LMG 3331 by the intramuscular route by following a protocol described previously (13). Sera taken before immunization were used as negative controls.

Serum absorption. Absorbed sera for ELISA and immunoelectrophoresis were obtained by mixing sera $(100 \mu \mathrm{l})$ with $2.5 \mathrm{mg}$ of freeze-dried cells or cytosol, respectively, and incubating them for $2 \mathrm{~h}$ at $37^{\circ} \mathrm{C}$ followed by $24 \mathrm{~h}$ at $4^{\circ} \mathrm{C}$. Immunoprecipitates were removed by centrifugation $(12,000 \times \mathrm{g}, 15 \mathrm{~min})$, and supernatants were collected.

\section{RESULTS}

Immunological cross-reactivity between Brucella and $O$. anthropi cytoplasmic proteins. Figure 1 shows the results of Western blot and double gel immunodiffusion analyses carried out with $B$. melitensis and $O$. anthropi cytosols. In Western blots, up to 10 Brucella and $O$. anthropi cytosolic components were detected with the heterologous hyperimmune sera (Fig. 1, lanes $\mathrm{Oa}$ and $\mathrm{Bm})$. As expected, the serum from a healthy human donor gave negative results with both cytosols (Fig. 1, lanes 1). In contrast, the serum of a human patient infected with $B$. melitensis contained antibodies to both the homologous and heterologous cytosols (Fig. 1, lanes 2). A Brucella-specific band with an apparent molecular weight of about 16,000 (16K) was detected in the cytosol of B. melitensis (Fig. 1, lanes 2), but antibodies to this component were not always present in eight other human sera tested (not shown). In addition, fainter 


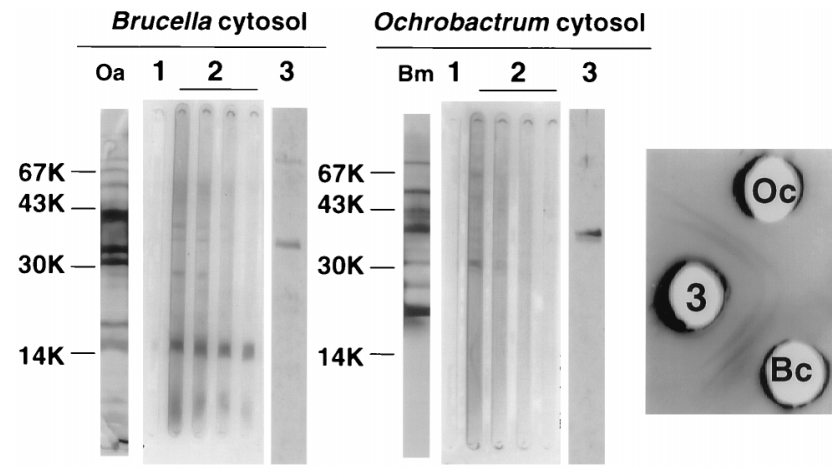

FIG. 1. Western blots (left and center) and double gel immunodiffusion (right) with cytosols from B. melitensis $(\mathrm{Bc})$ or $O$. anthropi $(\mathrm{Oc})$. The sera used were from rabbits hyperimmunized with $B$. melitensis $115(\mathrm{Bm})$, rabbits hyperimmunized with $\mathrm{R} O$. anthropi $(\mathrm{Oa})$, a healthy human donor (1), and a brucellosis patient (2) and pooled sera from six infected goats (3). Serum dilutions in Western blots were 1:25 (lanes Bm, Oa, 1, and 3) or 1:25 to 1:200 (lanes 2).

bands common to $O$. anthropi and Brucella cytosols were detected with the same patient serum, and titers were similar for the common components (Fig. 1, lanes 2). A pool of six $B$. melitensis-positive goat sera detected only a major band of about $35 \mathrm{~K}$ in both cytosols, although the apparent molecular weight of the $B$. melitensis band was slightly lower than that of the $O$. anthropi band (Fig. 1, lanes 3). The cross-reactivity between Brucella and $O$. anthropi cytosols was also observed in gel precipitation (Fig. 1, right panel, and Fig. 2), and more common components were clearly detected by this method than by immunoblotting. Moreover, reactions of total identity were observed in double gel immunodiffusion (Fig. 1, right panel), and as illustrated in Fig. 2, absorption of pools of sera from Brucella-infected hosts with the O. anthropi cytosol removed most, but not all, of the antibodies reacting with the homologous antigen.

These findings were extended by CIEP, a simple and sensitive test which allows the screening of large numbers of sera. Table 1 summarizes the CIEP results. As can be seen, the homologous and heterologous antigens had the same sensitivity in the detection of Brucella-infection of humans, goats, and cattle, and only 1 of the 35 sheep sera that developed precipitin lines with the $B$. melitensis cytosol failed to react with the $O$. anthropi cytosol. Sera from 208 Brucella-free hosts tested did not give positive results in CIEP with either cytosol. Since digestion of cytosols with proteinase $\mathrm{K}$ abrogated the reactiv-

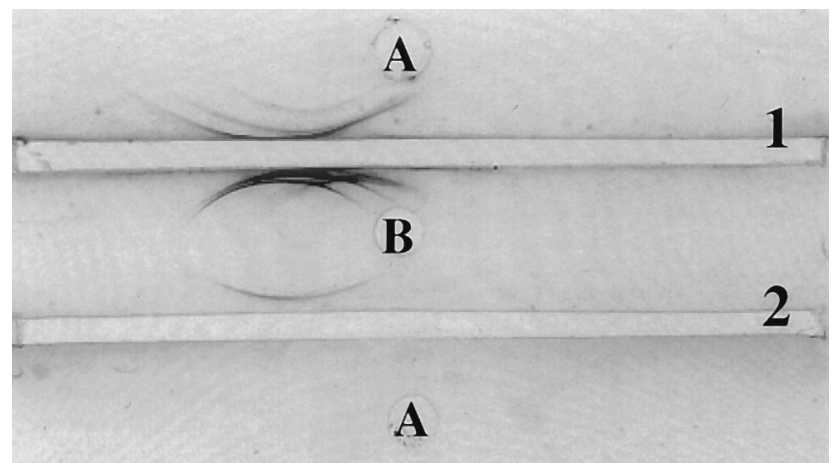

FIG. 2. Immunoelectrophoretic analysis of $O$. anthropi and B. melitensis cytosols (wells A and B, respectively). Trough 1 contained a pool of sera from $B$. melitensis-infected goats, and trough 2 contained the same pool absorbed with $O$. anthropi cytosol. The cathode is on the right.
TABLE 1. Results of CIEP with sera from hosts naturally infected with S Brucella spp.

\begin{tabular}{|c|c|c|c|c|}
\hline \multirow{2}{*}{ Host } & \multirow{2}{*}{ Status } & \multirow{2}{*}{$\begin{array}{l}\text { Total no. } \\
\text { of sera }\end{array}$} & \multicolumn{2}{|c|}{$\begin{array}{l}\text { No. of sera precipitating } \\
\text { cytosol of: }\end{array}$} \\
\hline & & & B. melitensis & O. anthropi \\
\hline \multirow[t]{2}{*}{ Humans } & Healthy & 10 & 0 & 0 \\
\hline & B. melitensis infected & 24 & 22 & 22 \\
\hline \multirow[t]{2}{*}{ Goats } & Brucella free & 66 & 0 & 0 \\
\hline & B. melitensis infected & 36 & 34 & 34 \\
\hline \multirow[t]{2}{*}{ Sheep } & Brucella free & 66 & 0 & 0 \\
\hline & B. melitensis infected & 36 & 35 & 34 \\
\hline \multirow[t]{2}{*}{ Cows } & Brucella free & 66 & 0 & 0 \\
\hline & B. abortus infected & 20 & 20 & 20 \\
\hline
\end{tabular}

ities, they were unequivocally assigned to protein antigens. The CIEP analyses also showed that the number of precipitin lines produced by a given serum was most often the same with both the homologous and heterologous cytosols, varying from one to four. These results were confirmed by reverse single radial diffusion.

Photomicrographs of the skin reactions at $72 \mathrm{~h}$ evoked by brucellin and the $O$. anthropi cytosolic fraction in the same B. ovis-infected ram are shown in Fig. 3. As can be seen, both showed the macrophage and lymphocyte infiltrations around dermis vessels characteristic of DTH reactions. Consistent with the presence of cross-reacting antibodies to $O$. anthropi and

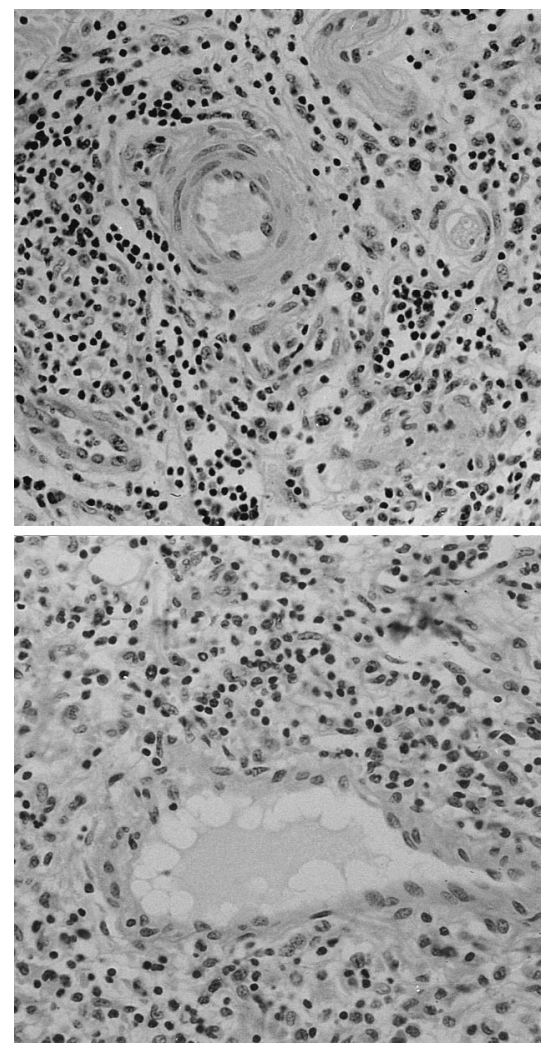

FIG. 3. Hematoxylin and eosin stain showing DTH reactions evoked by brucellin (top) and by the cytosol of $O$. anthropi (bottom) after intradermal inoculation into the same $B$. ovis-infected ram. Magnification, $\times 17.5$. 
TABLE 2. DTH responses to brucellin and to $O$. anthropi cytosol in mice infected with S Brucella and in rams infected with B. ovis

\begin{tabular}{|c|c|c|c|}
\hline \multirow{2}{*}{ Group } & \multirow{2}{*}{$\begin{array}{l}\text { No. of } \\
\text { animals }\end{array}$} & \multicolumn{2}{|c|}{$\begin{array}{c}\text { No. of animals showing } \\
\text { DTH to: }\end{array}$} \\
\hline & & Brucellin & $\begin{array}{l}\text { O. anthropi } \\
\text { cytosol }\end{array}$ \\
\hline Mice inoculated with B. abortus 2308 & 5 & 3 & 3 \\
\hline Mice inoculated with $B$. melitensis $16 \mathrm{M}$ & 5 & 5 & 3 \\
\hline Brucella-free mice & 5 & 0 & 0 \\
\hline Rams infected with $B$. ovis & 14 & 14 & 14 \\
\hline Brucella-free rams & 15 & 0 & 0 \\
\hline
\end{tabular}

Brucella proteins, leukocytes indicative of a mixed-type reaction were also detected in some cases (not shown). When DTH test results for B. melitensis- or B. abortus-infected mice and $B$. ovis-infected rams were compared, a close parallelism in the number of animals showing DTH to brucellin and to $O$. anthropi cytosol was found (Table 2).

Immunological cross-reactivity between Brucella and $O$. anthropi LPSs. Sera from B. melitensis-infected rabbits or naturally infected hosts failed to react significantly with the S-LPS and the O-specific polysaccharide of $O$. anthropi in ELISA, although sera from rabbits immunized with the homologous strain showed a strong reactivity (not shown). However, some reactivity was observed in Western blots with the $O$. anthropi S-LPS and the sera of animals infected with S Brucella spp. (not shown), suggesting cross-reactions at the core and/or lipid A level.

SDS-PAGE analysis showed predominantly R-LPS in the petroleum ether-chloroform-phenol extract of $O$. anthropi LMG 3301 (Fig. 4A, lane 1), and consistent with the nature of the extract, no material was detected in the lipid A-rich fraction by silver-periodate staining (Fig. 4A, lane 2). As determined by Western blotting, sera from rabbits immunized with live $\mathrm{R} O$. anthropi contained $\mathrm{IgG}$ to the homologous R-LPS (Fig. 4B, lane 1) but not to the lipid A-rich fraction (Fig. 4B, lane 2). However, the sera from $\mathrm{S} B$. melitensis-infected rabbits which were bled 45 days or 3 months after infection (but not 15 days or 6 months after infection) had IgG to both the R-LPS and the lipid A-rich fraction (Fig. 4C, lanes 1 and 2). Consistent with these results, ELISAs showed similar levels of IgG (optical density readings from 1.6 to 1.2 for the 1:50 serum dilution) reacting with $O$. anthropi R-LPS or with the lipid A-rich fraction in the sera of rabbits infected with $B$. melitensis or immunized with live $O$. anthropi. Low and variable levels of $\mathrm{IgG}$ (optical density readings from 0.6 to 0.2 for the $1: 50$ serum dilution) to these extracts were detected in the sera from $B$. abortus-infected cattle and B. melitensis-infected sheep, goats, and humans (not shown). All the above-mentioned reactivities were abrogated by absorbing the sera with whole $\mathrm{R}$ cells $(B$. abortus RB51 or O. anthropi LMG 3301) (not shown).

Since the homologous R-LPS is an immunodominant antigen in $B$. ovis infections $(21,39)$, the reactivities of the $O$. anthropi and $B$. ovis R-LPSs were compared by using sera from rams experimentally infected with $B$. ovis (Fig. 5A and B). These sera showed similar reactivities with the homologous and heterologous R-LPS, and reactivity with the lipid A-rich fraction of $O$. anthropi was also detected (Fig. 5C).

Immunological cross-reactivity between Brucella and $O$. anthropi OM proteins. Figure 6 shows representative results of Western blot analyses performed with extracts rich in $\mathrm{OM}$ proteins and pools of sera from six B. ovis-infected rams (Fig. 6A) and from six B. melitensis-infected goats (Fig. 6B). Both pools contained IgG to B. melitensis (Fig. 6, lanes 1 ) and B. ovis (lanes 4) OM proteins with apparent molecular weights close to $38 \mathrm{~K}$ and $28 \mathrm{~K}$, but no reaction was observed with an Escherichia coli OM protein extract (lanes 3 ) obtained as described elsewhere (36). The same sera recognized a protein of about $28 \mathrm{~K}$ present in the $O$. anthropi OM extract (lanes 2). A pool of sera from $B$. abortus-infected cattle showed a much weaker reactivity at the same dilution (not shown). The bands corresponding to the R-LPS were clearly detected with the ram sera and the Brucella OM extracts (Fig. 6A, lanes 1 and 4), but consistent with the ELISA results, the sera from $B$. melitensisinfected goats did not reveal the R-LPS in the $O$. anthropi extract (Fig. 6B, lane 2).

\section{DISCUSSION}

The results presented show that an immune response to $O$. anthropi antigens is consistently elicited by experimental and natural infections with $B$. ovis, $B$. melitensis, and $B$. abortus in a variety of hosts. As illustrated by some of the Western blotting results, serological cross-reactions among taxonomically related bacteria can be shown with sera from hyperimmunized animals (8). However, in this study the cross-reactivity was observed not only with hyperimmune sera but also with sera from hosts with natural or experimental brucellosis, and crossreactivity was also detected in the DTH skin test. In this regard, Brucella proteins elicit cell- and antibody-mediated immunoresponses which have been investigated for diagnostic purposes $(4,7,10,14,17,20,28,30,32,37,39,42-44,46,50$, 51). Therefore, it is noteworthy that the diagnostic sensitivity obtained with the homologous and heterologous cytosols was the same and that cross-absorption removed most of the antibodies to the homologous cytosol. It is also interesting that, compared with gel immunoprecipitation, immunoblotting with cytosols detected fewer antigens shared by $O$. anthropi and Brucella, suggesting the importance of conformational epitopes in the cross-reactions.

The above-discussed observations show that the $O$. anthropi antigens detected by the sera from Brucella-infected hosts are of diagnostic significance in brucellosis. Since cell-mediated immunoresponses to proteins are important in brucellosis $(7,20)$, this conclusion is further supported by the fact that $O$. anthropi cytosolic proteins evoked a DTH response of a frequency and intensity similar to that evoked by Brucella proteins. Infections by $Y$. enterocolitica $0: 9$ and a few other gramnegative bacteria cause false-positive reactions in tests detect-

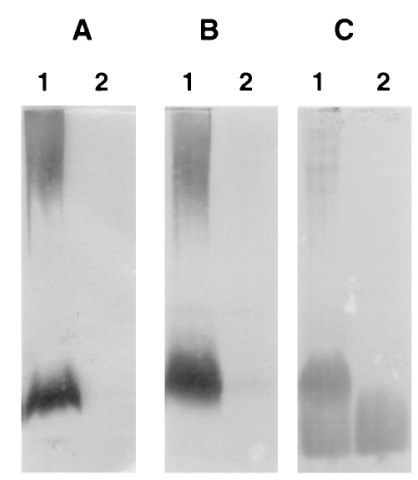

FIG. 4. SDS-PAGE for LPS (A) and Western blot (B and C) analyses of $O$. anthropi R-LPS (lanes 1) and lipid A-rich fraction (lanes 2). The sera used (1:50 dilution) were from rabbits immunized with live $\mathrm{R} O$. anthropi (B) or infected with S B. melitensis (C). 

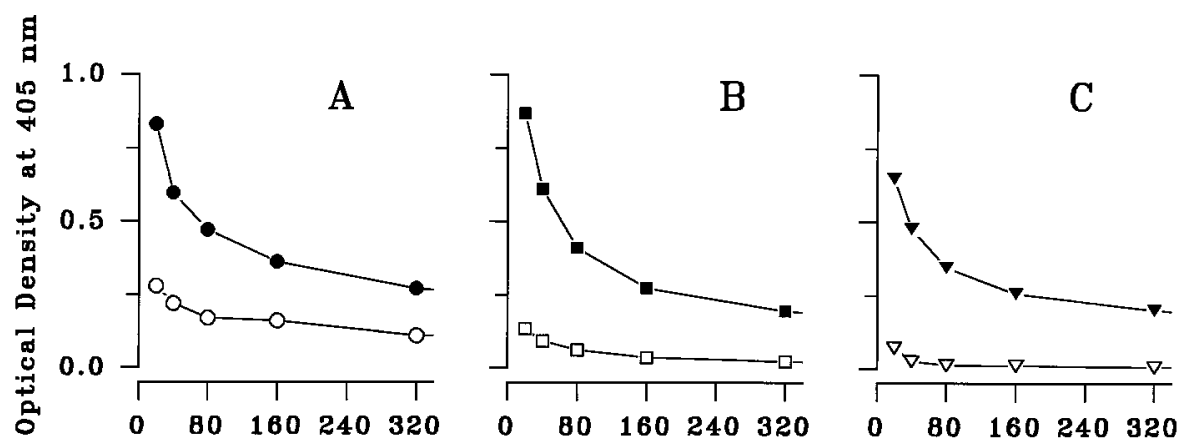

\section{Serum Dilutions}

FIG. 5. Analysis by ELISA of the presence of IgG to B. ovis R-LPS (A), to O. anthropi R-LPS (B), and to an $O$. anthropi lipid A-rich fraction (C). Filled symbols represent results with the sera of 21 B. ovis-infected rams, and open symbols represent results with the sera of 21 Brucella-free rams.

ing antibodies to Brucella S-LPS $(4,5)$. On the other hand, no cross-reactivity with proteins of other bacteria has been reported (11), and this is one reason for developing tests with Brucella proteins $(5,15,18)$. Although some of the more promising Brucella proteins are cytosolic $(26,44)$, and the crossreactivity described above could suggest that Brucella antiprotein tests are less specific than previously thought, the fact is that we did not detect antibodies to $O$. anthropi proteins in the 208 sera from Brucella-free hosts tested or DTH responses in the Brucella-free rams. Because of the bacterium's multiple and variable antibiotic resistance patterns $(6,29)$ and reported isolation from a soil invertebrate (1), it seems likely that the primary habitat of $O$. anthropi is the soil. To the best of our knowledge, isolation of $O$. anthropi from livestock has not been attempted, but this bacterium has been repeatedly described as an opportunistic pathogen of humans $(9,27)$, and some of these patients develop antibodies cross-reacting with Brucella antigens (33). Thus, although our results with the Brucella-free animals show that it is unlikely, the possibility that $O$. anthropi represents a source of nonspecificity in antiprotein tests for brucellosis cannot presently be excluded (see below).

Research carried out with sera from humans and animals infected with S Brucella spp. has shown that the S-LPS, and to a much lesser extent several OM proteins, is the major antigen of the Brucella cell surface (10, 12, 15, 17, 18, 23, 39, 50). No

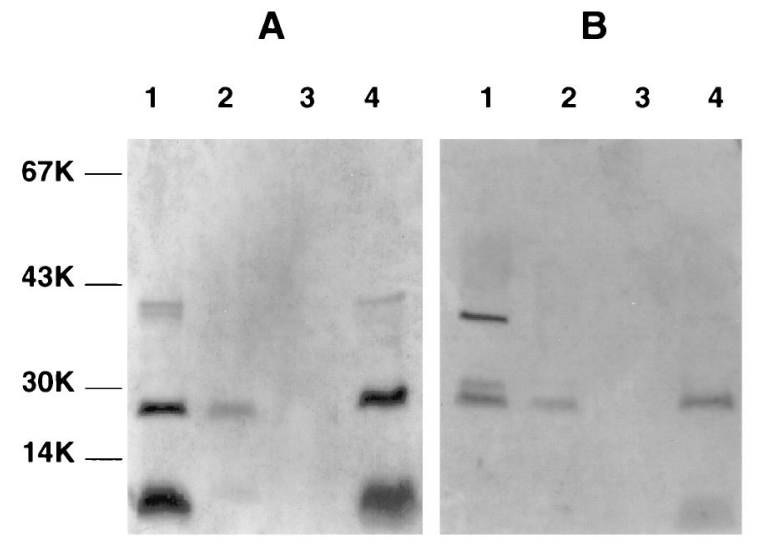

FIG. 6. Western blots with OM-rich extracts from R B. melitensis (lanes 1), R O. anthropi (lanes 2), E. coli O111 (lanes 3), and B. ovis (lanes 4). The sera used (1:50 dilution) were pools from six infected rams (A) or from six infected goats (B). serological reactivity between sera from Brucella-infected animals and the S-LPS of $O$. anthropi was observed. This is in agreement with the characterization of the corresponding $\mathrm{O}$ chains as polymers of $N$-formylperosamine (38) and of a glucosamine-rhamnose disaccharide (48). However, a significant cross-reactivity between some sera from hosts infected with Brucella spp. and both the $O$. anthropi R-LPS and the lipid A-rich fraction was observed. In particular, comparison of $O$. anthropi and $B$. ovis R-LPSs in ELISAs with sera from rams experimentally infected with $B$. ovis showed that both antigens would have the same diagnostic value in this assay. The LPS core of $O$. anthropi contains galacturonic acid (49), which is not found in Brucella, but also Kdo, glucose, and glucosamine (49), which are present in Brucella LPS (35). Although the crossreactivity observed can be accounted for by core epitopes, the reactivity observed with the lipid A-rich fraction shows that lipid A antigenic determinants (40) also contribute significantly. Antibodies to the homologous core and lipid A determinants in the sera of S Brucella-infected animals have been reported previously $(3,40)$.

It has been a constant observation that $B$. ovis-infected sheep show high background reactivities with the homologous R-LPS when tested in ELISA with conjugates of heavy- and light-chain specificity, and this reactivity can be removed in part by using IgG-specific conjugates (21). Moreover, previous comparative studies have shown that although the antibody response to group $3 \mathrm{OM}$ proteins is more intense in $B$. ovisthan in B. melitensis-infected sheep (39), sera from Brucellafree sheep often contain low titers of antibodies reacting with group 3 OM proteins $(23,39)$. We have hypothesized that such antibodies could be elicited by some unknown ubiquitous bacteria (23), and the data presented here point to $O$. anthropi, and perhaps to some unknown taxonomically related bacteria, as the logical candidates.

\section{ACKNOWLEDGMENTS}

This research was supported in part by the Dirección General de Investigación Científica y Tecnológica (AGF95-1013-CO2), by the Instituto Nacional de Investigaciones Agrarias (SC95-037), and by a grant from Gobierno de Navarra. Fellowship support for J. Velasco and M. J. Grilló from the Ministerio de Educación, Ciencia y Tecnología of Spain is gratefully acknowledged.

\section{REFERENCES}

1. Aguillera, M. M., N. C. Hodge, R. E. Stall, and G. C. Smart, Jr. 1993 Bacterial symbionts of Steinernema scapterisci. J. Invertebr. Pathol. 68:68-72. 2. Alnor, D., N. Frimoldt-Moller, F. Espersen, and W. Frederiksen. 1994. 
Infections with the unusual human pathogens Agrobacterium species and Ochrobactrum anthropi. Clin. Infect. Dis. 18:914-920.

3. Alonso-Urmeneta, B., I. Moriyón, R. Díaz, and J. M. Blasco. 1988. Enzymelinked immunosorbent assay with Brucella native hapten polysaccharide and smooth lipopolysaccharide. J. Clin. Microbiol. 26:2642-2646.

4. Alton, G. G., L. M. Jones, R. D. Angus, and J. M. Verger. 1988. Techniques for the brucellosis laboratory. Institut National de la Recherche Agronomique, Paris, France.

5. Baldi, P. C., G. H. Giambartolomei, F. A. Goldbaum, L. F. Abdón, C. A. Velikovsky, R. Kittelberger, and C. A. Fossati. 1996. Humoral immune response against lipopolysaccharide and cytoplasmic proteins of Brucella abortus in cattle vaccinated with $B$. abortus S19 or experimentally infected with Yersinia enterocolitica serotype 0:9. Clin. Diagn. Lab. Immunol. 3:472476.

6. Bizet, C., and J. Bizet. 1995. Sensibilité comparée de Ochrobactrum anthropi, Agrobacterium tumefaciens, Alcaligenes faecalis, Alcaligenes denitrificans subsp. denitrificans, Alcaligenes denitrificans subsp. xylosoxidans et Bordetella bronchiseptica vis-à-vis de 35 antibiotiques dont 17 beta-lactamines. Pathol. Biol. 43:258-263.

7. Blasco, J. M., C. Marín, M. Jiménez de Bagués, M. Barberán, A. Hernández, L. Molina, J. Velasco, R. Díaz, and I. Moriyón. 1994. Evaluation of allergic and serological tests for diagnosing Brucella melitensis infection in sheep. J. Clin. Microbiol. 32:1835-1840.

8. Bowden, G. H. W. 1993. Serological identification, p. 429-462. In M. Goodfellow and A. G. O'Donnell (ed.), Handbook of new bacterial systematics. Academic Press, London, England.

9. Cieslak, T. J., M. L. Robb, C. J. Drabick, and G. W. Fischer. 1992. Catheterassociated sepsis caused by Ochrobactrum anthropi: report of a case and review of related nonfermentative bacteria. Clin. Infect. Dis. 14:902-907.

10. Cloeckaert, A., P. Kerkhofs, and J. N. Limet. 1992. Antibody response to Brucella outer membrane proteins in bovine brucellosis: immunoblot analysis and competitive enzyme-linked immunosorbent assay using monoclonal antibodies. J. Clin. Microbiol. 30:3168-3174.

11. Díaz, R., and N. Bosseray. 1974. Estudio de las relaciones antigénicas entre Yersinia enterocolitica serotipo $9 \mathrm{y}$ otras especies bacterianas gram-negativas. Microbiol. Esp. 27:1-14.

12. Diaz, R., L. M. Jones, D. Leong, and J. B. Wilson. 1968. Surface antigens of smooth brucellae. J. Bacteriol. 96:893-901.

13. Diaz, R., L. M. Jones, and J. B. Wilson. 1968. Antigenic relationship of the gram-negative organism causing canine abortion to smooth and rough brucellae. J. Bacteriol. 95:618-624.

14. Díaz, R., E. Maraví-Poma, and A. Rivero. 1976. Comparison of counterimmunoelectrophoresis with other serological tests in the diagnosis of human brucellosis. Bull. W. H. O. 53:417-424.

15. Díaz, R., and I. Moriyón. 1989. Laboratory techniques in the diagnosis of human brucellosis, p. 73-83. In E. J. Young and M. J. Corbel (ed.), Brucellosis: clinical and laboratory aspects of human infection. CRC Press, Inc., Boca Raton, Fla.

16. Díaz-Aparicio, E., V. Aragón, C. Marín, B. Alonso, M. Font, E. Moreno, S. Pérez-Ortiz, J. M. Blasco, R. Díaz, and I. Moriyón. 1993. Comparative analysis of Brucella serotype A and M and Yersinia enterocolitica O:9 polysaccharides for serological diagnosis of brucellosis in cattle, sheep, and goats. J. Clin. Microbiol. 31:3136-3141.

17. Díaz-Aparicio, E., C. Marín, B. Alonso-Urmeneta, V. Aragón, S. Pérez-Ortiz, M. Pardo, J. M. Blasco, R. Díaz, and I. Moriyón. 1994. Evaluation of serological tests for diagnosis of Brucella melitensis infection of goats. J. Clin. Microbiol. 32:1159-1165.

18. Dubray, G. 1984. Progrès récents sur la biochimie et les propriétés biologiques des antigènes de Brucella. Dev. Biol. Stand. 56:131-150.

19. Ezzedine, H., M. Mouraud, C. Van Ossel, C. Logghe, J. P. Squifflet, F. Renault, G. Wauters, J. Gigi, L. Wilmotte, and J. J. Haxhe. 1994. An outbreak of Ochrobactrum anthropi bacteremia in five organ transplant patients. J. Hosp. Infect. 27:35-42.

20. Fensterbank, R. 1985. Allergic diagnosis of brucellosis, p. 167-172. In M. Plommet and J. M. Verger (ed.), Brucella melitensis. Martinus Nijhoff Publishers, Dordrecht, The Netherlands.

21. Ficapal, A., B. Alonso-Urmeneta, I. Moriyón, J. Velasco, and J. M. Blasco. 1995. Diagnosis of Brucella ovis infection of rams using an ELISA with protein $\mathrm{G}$ as conjugate. Vet. Rec. 137:145-147.

22. Galanos, C., O. Lüderitz, and O. Westphal. 1969. A new method for the extraction of R lipopolysaccharide. Eur. J. Biochem. 9:245-249.

23. Gamazo, C., A. J. Winter, I. Moriyón, J. I. Riezu-Boj, J. M. Blasco, and R. Díaz. 1989. Comparative analyses of proteins extracted by hot saline or released spontaneously into outer membrane blebs from field strains of Brucella ovis and Brucella melitensis. Infect. Immun. 57:1419-1426.

24. Goldbaum, F. A., C. P. Rubbi, J. C. Wallach, S. E. Miguel, P. C. Baldi, and C. A. Fossati. 1992. Differentiation between active and inactive human brucellosis by measuring antiprotein humoral immune responses. J. Clin. Microbiol. 30:604-607.

25. Grandsden, W. R., and S. J. Eykyn. 1992. Seven cases of bacteremia due to Ochrobactrum anthropi. Clin. Infect. Dis. 15:1068-1069.
26. Hemmen, F., V. Weynants, T. Scarcez, J.-J. Letesson, and E. Saman. 1995. Cloning and sequence analysis of a newly identified Brucella abortus gene and serological evaluation of the 17-kilodalton antigen that it encodes. Clin. Diagn. Lab. Immunol. 2:263-267.

27. Holmes, B., M. Popoff, M. Kiredjian, and K. Kersters. 1988. Ochrobactrum anthropi gen. nov., sp. nov. from human clinical specimens and previously known as group Vd. Int. J. Syst. Bacteriol. 38:406-416.

28. Iannelli, D., R. Diaz, and T. M. Bettini. 1976. Identification of Brucella abortus antibodies in cattle serum by single radial diffusion. J. Clin. Microbiol. 3:203-205.

29. Kern, W. V., M. Oethinger, A. Kaufhold, E. Rozdzinski, and R. Marre. 1993. Ochrobactrum anthropi bacteremia: report of four cases and short review. Infection 21:306-310.

30. Leiva, J., J. Mendoza, J. M. Navarro, J. C. Plata, and M. de la Rosa. 1990 Patrón de anticuerpos en brucelosis humana aguda definido por Western blot. Enferm. Infecc. Microbiol. Clin. 8:33-36.

31. Leong, D., R. Diaz, K. Milner, J. Rudbach, and J. B. Wilson. 1970. Some structural and biological properties of Brucella endotoxin. Infect. Immun. 1:174-182.

32. Lin, J., L. G. Adams, and T. A. Ficht. 1992. Characterization of the heat shock response in Brucella abortus and isolation of the genes encoding the GroE heat shock proteins. Infect. Immun. 60:2425-2431.

33. Marrodán, T., J. Velasco, M. Rubio, I. Moriyón, and R. Díaz. Unpublished data.

34. Moreno, E. 1992. Evolution of Brucella, p. 198-218. In M. Plommet (ed.), Advances in brucellosis research. Pudoc Scientific Publishers, Wageningen, The Netherlands.

35. Moreno, E., L. M. Jones, and D. T. Berman. 1984. Immunochemical characterization of rough Brucella lipopolysaccharides. Infect. Immun. 43:779782.

36. Moriyon, I., and D. T. Berman. 1982. Effects of nonionic, ionic, and dipolar ionic detergents and EDTA on the Brucella cell envelope. J. Bacteriol. 152:822-828.

37. Muhammed, S. I., H. Mohammadi, and H. Saadi-Nam. 1980. A comparison of counterimmunoelectrophoresis with the rose bengal and the serum tube agglutination tests in the diagnosis of brucellosis in sheep. Vet. Microbiol. 5:223-227.

38. Perry, M. B., and D. R. Bundle. 1990. Lipopolysaccharide antigens and carbohydrates of Brucella, p. 76-88. In L. G. Adams (ed.), Advances in brucellosis research. Texas A\&M University Press, College Station.

39. Riezu-Boj, J. I., I. Moriyón, J. M. Blasco, C. Gamazo, and R. Díaz. 1990. Antibody response to Brucella ovis outer membrane proteins in ovine brucellosis. Infect. Immun. 58:489-494.

40. Rojas, N., E. Freer, A. Weintraub, M. Ramirez, S. Lind, and E. Moreno. 1994. Immunochemical identification of Brucella abortus lipopolysaccharide epitopes. Clin. Diagn. Lab. Immunol. 1:206-213.

41. Romero, C., C. Gamazo, M. Pardo, and I. López-Goñi. 1995. Specific detection of Brucella DNA by PCR. J. Clin. Microbiol. 33:615-617.

42. Roop, R. M., II, T. W. Fletcher, N. M. Sriranganathan, S. M. Boyle, and G. G. Schurig. 1994. Identification of an immunoreactive Brucella abortus HtrA stress response protein homolog. Infect. Immun. 62:1000-1007.

43. Rossetti, O. L., A. I. Arese, M. L. Boschiroli, and S. L. Cravero. 1996 Cloning of Brucella abortus gene and characterization of expressed 26-kilodalton periplasmic protein: potential use for diagnosis. J. Clin. Microbiol. 34:165-169.

44. Salih-Alj Debbarh, H., A. Cloeckaert, G. Bézard, G. Dubray, and M. S. Zygmunt. 1996. Enzyme-linked immunosorbent assay with partially purified cytosoluble 28-kilodalton protein for serological differentiation between $\mathrm{Bru}$ cella melitensis-infected and B. melitensis Rev.1-vaccinated sheep. Clin. Diagn. Lab. Immunol. 3:305-308.

45. Schurig, G. G., R. M. Roop II, T. Bagchi, S. Boyle, D. Buhrman, and N. Sriranganathan. 1991. Biological properties of RB51; a stable rough strain of B. abortus. Vet. Microbiol. 28:171-188.

46. Tabatabai, L. B., and S. G. Hennager. 1994. Cattle serologically positive for Brucella abortus have antibodies to B. abortus $\mathrm{Cu}-\mathrm{Zn}$ superoxide dismutase Clin. Diagn. Lab. Immunol. 1:506-510.

47. Tall, B. D., H. N. Williams, K. S. George, R. T. Gray, and M. Walch. 1995 Bacterial succession within a biofilm in water supply lines of dental air-water syringes. Can. J. Microbiol. 41:647-654.

48. Velasco, J., H. Moll, E. Vinogradov, I. Moriyón, and U. Zähringer. 1996 Determination of the O-specific polysaccharide structure in the lipopolysaccharide of Ochrobactrum anthropi LMG 3331. Carbohydr. Res. 287:123-126.

49. Velasco, J., H. Moll, V. Sinnwell, I. Moriyón, and U. Zähringer. Unpublished data.

50. Zygmunt, M. S., A. Cloeckaert, and G. Dubray. 1994. Brucella melitensis cell envelope protein and lipopolysaccharide epitopes involved in humoral immune responses of naturally and experimentally infected sheep. J. Clin. Microbiol. 32:2514-2522.

51. Zygmunt, M. S., F. B. Gilbert, and G. Dubray. 1992. Purification, characterization, and seroactivity of a 20-kilodalton Brucella protein antigen. J. Clin. Microbiol. 30:2662-2667. 